Fee Alexandra Haase ${ }^{1}$

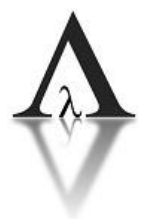

DOI: 10.31902/LL.2019.6.1.1

\title{
SPEECH AND ITS DIMENSIONS. A CASE OF THE EMERGENCE, TRADITION AND CONTINUITY OF THE THEORY OF RHETORIC IN THE CONTEMPORARY DIGITAL MEDIA LANDSCAPE
}

\begin{abstract}
Less research today is interested in the contemporary place of speech as communicated contents in the contemporary media landscape, which is drastically different from historical stages of media use with speech as a phenomenon of orality or literality. Despite its foundation in rhetoric as associated theory and practice of oral speech, the theory of rhetoric has provided us since Greek antiquity with a stable and established approach for a theoretical reflection of media and speech. This article presents the main concepts of speech that are today used in different approaches to research. It describes the historical elements of rhetoric for a typological approach to speech in five dimensions (speech as the realization of language, as an utterance, as a discourse, as a genre of traditional rhetoric, and as mediated contents). Finally, it discusses and demonstrates how these dimensions are elements of the production process of persuasive rhetoric in the theory of rhetoric that is present in the current media landscape with oral communication, speech in mechanical media, legacy media, and new media.
\end{abstract}

Key Words: speech, rhetoric, theory, linguistics, legacy media, new media, orality/literality

\section{Introduction}

Speech is a genuine human ability to communicate and the product of this communication process. After its emergence as a human feature, the use of speech was in the course of the development of humankind augmented by new communication media and employed in various communicative situations. Today speech as the exchange of words can be found in many technical devices, especially digital media. This situation challenges the question of the continuity of the theory of rhetoric that developed in ancient Greece for a theoretical approach to the contemporary media landscape. The aim of this article is to show how the concept of speech has a fundamental function for the description of the media landscape today. It uses the approach of the theory of rhetoric, which has the oldest tradition as an academic

\footnotetext{
${ }^{1}$ Associate Professor at the Department of Humanities and Social Sciences of the United International College in Zhuhai, China.
} 
discipline that is interested in the form and functions of speech. The article applies this approach to the contemporary media landscape of the 21st century. The article presents a review of the approaches to speech in different traditions of research fields (part I.) and a conceptual description of the concept of speech in five dimensions (part II.). In the next part, the conceptual dimensions will be applied to the contemporary situation. The relation of these five dimensions of the concept of speech to the classical elements of speech production in the theory of rhetoric will be shown. Contemporary examples will be presented for the relevance of these classical elements of speech in a description of the functions of media and their elements in the contemporary media landscape (part III.).

\section{Part I.}

\section{Approaches to Research on Speech}

In this Part I., we introduce the perspectives on speech as a phenomenon of the world we experience as humans who are intellectually able to recognize and frame speech in the setting of other experiences. Research about speech actually starts at the point when humans developed a notion about it, named it as a means of distinction, and inquired into its features.

\section{Speech and its Representation: Setting Up a Human Metadis- course}

Humans are able to reflect on what they are saying and can use words for making utterances. Unfortunately, due to the limits of our empirical knowledge of languages before the age of historical accounts, we cannot determine when in the past of humanity the abstract concept of speech actually became part of the vocabulary used. We have in the historical linguistic branch of language studies the approach of the reconstruction of words of hypothetical languages around the world. All hypothetical languages contain word stems with phonemes for the semantic representation of activities of speaking. Starostin's project Tower of Babel provides the documentation of such stems for the main language families. The distinction between language as a system and speech, which is usually attributed to the beginnings of linguistics and De Saussure's distinct terms of 'langue' and 'parole', can be found already in the ancient Egyptian language. Here the word 'md.t' means 'language', while for the uttered form of speech the word 'r3' is used (Wörterbuch der Ägyptischen Sprache. Vol. VI. 1971: 145). In the Akkadian language, this distinction is not so obvious, but many differentiations of what we call language varieties today existed. 'Lišānu' comprises as meanings 'tongue', 'language', and 'speech'. 'Lišānum' has the meanings 'tongue', 
'language as instrument of prayer or malice', 'dialect', and 'pronunciation' in the Akkadian Dictionary of the Association Assyrophile de France (2019).

In Greek and Latin, the terms ' $\lambda o ́ \gamma o s^{\prime}$ and 'oratio' are the classical term for formal speech in rhetorical treatises since antiquity with an impact on the European languages in modernity that still employ them. Both terms are used for the description of a unit of speech that is composed according to the principles of rhetoric. Obviously, besides ' $\lambda$ óyos' and 'oratio' other terms existed during the classical age throughout history that were employed for speech as a spoken unit of linguistically meaningful contents of communication processes. In classical Greek, the word ' $\lambda \alpha \lambda$ ı $\alpha$ ' is used for speech uttered in an informal way. While the word was not employed in classical Greek sources of philosophers and rhetoricians, it was commonly used in the Late Hellenistic Age among the writers of the New Testament. The Latin word 'sermo' was is listed for an informal vernacular speech in contrast to the formal 'oratio' in the Dictionary Entry Lookup Tool of Perseus Project (2019). As a condition of research, we have to face the condition of the relativity of the language we employ for the topic of our research and as terminology. The semantic borders for words that refer to the concept of speech are in different languages not identical. This difference occurs even among closely related languages. For example, in the English language, the word language, a word related to the Latin word lingua for 'language', and the word 'speech', which is related to a Germanic root, exist, while the German language only uses the word Sprache for both meanings. The metadiscourse about speech is conditionalized and framed by the conceptualization of speech in a particular language.

\section{Speech and Linguistics: Disciplinary Framing of Words}

Speech can be understood as a unit of linguistically constructed utterances with sounds. Holden (2004: 1316) mentions that skeletal studies allow for speech as "producing the sounds of words, or phonemes" the assumption that the human anatomy with a modern position of the larynx increases the range of sounds of humans: "By about 300,000 years ago, our ancestors had become more or less 'modern' anatomically, and they possessed a larynx located at the top of the trachea, lower than in other primates". Other approaches of linguistics like the Chomskian approach employ language as a purely theoretical concept open for speculative theories. So for Berwick, Bolhuis, Chomsky, and Tattersall, it is a 'misconception' that

"language is coextensive with speech and that the evolution of vocalization or auditory-vocal learning can therefore inform us about 
the evolution of language. However, speech and speech perception, while functioning as possible external interfaces for the language system, are not identical to it. An alternative externalization of language is in the visual domain, as sign language" (2014: 1).

This approach takes into account what De Saussure distinguished as the difference of language as a system ('langue') and uttered speech ('parole') in his Course in General Linguistics, originally published as Cours de Linguistique Générale in the year 1916. De Saussure defines language ('langue') here as an 'object of linguistics' ('objet de la linguistique') in chapter III (1971: 23-24) and distinguishes in chapter IV Linguistique de la Langue et Linguistique de la Parole (1971: 36-40) these two areas of research.

Important for the research process about mediated forms of speech is the focus on the development of speech as an extending human faculty with connectivity to other cultural products of the humankind and a variety of representations. Bakhtin had a late, but important impact on the study of speech and its rhetorical tradition in the West after his works were translated into Western languages. Bakhtin's Speech Genres and Other Late Essays, first published in 1986 in English, was republished in 2008. Bakhtin here focuses on the literary impact of rhetoric and sees the tradition of the poetic literary tradition of the Bildungsroman in the cultural movement of the 'Second Sophistic', when the genre romance emerged based on rhetorical elements:

"The Greek romance rising out of the 'Second Sophistic' and nourished on rhetorical casuistry - creates basically a rhetorical, juridical concept of man. Here one already sees the image of a human being who is profoundly steeped in those judicial-rhetorical categories and concepts of guilt/innocence, judgment/vindication, accusation, crime, virtue, merits, and so forth, which have for so long hung suspended over the novel and dictated the presentation of the hero in the novel as accused or defended, transforming the novel into a kind of court of law for the hero" (1986: 12).

In The Problem of Speech Genres, Bakhin (1986: 61) mentions that literary genres have not been studied "as specific types of utterances distinct from other types, but sharing with them a common verbal (language) nature. The general linguistic problem of the utterance and its types has hardly been considered at all. Rhetorical genres have been studied since antiquity (and not much has been added in subsequent epochs to classical theory." Bakhtin here suggests a difference between 'primary (simple) speech genres' and 'secondary (complex) speech genres' comprising novels, dramas, all kinds of scientific research, major genres of commentary and others, which "arise in more complex and 
comparatively highly developed and organized cultural communication (primarily written) that is artistic, scientific, sociopolitical, and so on" (1986: 61). Bakhtin clearly distinguishes 'rhetorical genres', 'literary genres', and 'speech genres', which emerge in the process of 'cultural communication'. The literary focus of Bakhtin's works is obvious and deserves the place as a work of the history of literature with an approach to an extended conceptualization of literary works. We can consider Bakhin's work as an initial study of the transfer of the concept of speech to the medium of written linguistic representations.

While theoretical linguistics has established the terms and concepts for the description of any linguistic phenomenon, it is the particular area of text studies that seeks to expand the concept of the text to types and genres with a typological approach. In the article Evolving Genres in Online Domains: The Hybrid Genre of the Participatory News, Bruce provided an overview of approaches for the categorization of texts in terms of genres mentioning in his review of research the existence of "key difficulties in establishing systematic and comprehensive models that are able to account for all of the types of knowledge that writers and readers draw upon in order to identify and ratify a text as belonging to a particular genre category" (2011: 323). The conceptualization of speech as a text allows us to understand complex representations of speech across media and the classification of speech as a media text. Nevertheless, text is a holistic compositional concept for a binding structure, and not for the bound material. The concept can only in a typological approach of structures be used as a means for the description of overarching characteristic features of speech realized in its particular environment.

\section{Speech and Discourse: Speech beyond Speaking}

The concept of discourse is broad; in empirical research, as its simplest application, it relates to the study of speech in conversations among people as an event of communicative exchange. In the linguistic approach, the concept of discourse is limited to aspects of theoretical linguistics. In Discourse Analysis: What Speakers Do in Conversation, Tannen (2019) states:

"Discourse analysis is sometimes defined as the analysis of language 'beyond the sentence'. This contrasts with types of analysis more typical of modern linguistics, which are chiefly concerned with the study of grammar: the study of smaller bits of language, such as sounds (phonetics and phonology), parts of words (morphology), meaning (semantics), and the order of words in sentences (syntax). Discourse analysts study larger chunks of language as they flow together." 
But in an overarching disciplinary approach, the concept of discourse refers to any speech in any mediated setting concerning a topic with the 'universe of discourse'. It is the set of all virtual statements that can be made about a particular topic. Usó-Doménech, Nescolarde-Selva, and Gash in Universe of Discourse and Existence ask if a 'universe of discourse' as a notion is related to existence and concluded that "it is possible to deduce that formal existence is nothing other than belonging to the universe of discourse" and that "no universe of discourse is given in advance" and "any universe of discourse that satisfies the necessary conditions can be used" (2018: 1-19). Even in the theoretical approach, the concept of the 'universe of discourse' reflects what exists as an evidential reality for us. Linguistic utterances are one possible type of representation of a particular topic. Marcuse used the idea of the closing of the universe of discourse for the lack of shared communication in a society in the second chapter The Closing of the Political Universe of OneDimensional Man (1964). The approach to speech as a realization of discourse is important since it allows researchers to study the structure of speech beyond the level of theoretical linguistics. Michel Foucault's studies about the relation of discourse and power and Teun A. van Dijk's works about media for the formation of discourse are dedicated to studying the discourse beyond speech as interpersonal communication. Discourse studies allow approaches in a variety of media and multimedia forms, which treat a common topic beyond the level of oral conversations.

\section{Speech and rhetoric: normative rules of speaking. The case of genres of speech in ancient Greek and Roman rhetorical treatises}

Classical rhetoric is as 'rhetorica docens' a set of normative instructions for the production of speeches, which are classified in the rhetorical theory as a genre ('genus'). This classification consists of three types in accordance with the area of the discourse of society as an epideictic, juridical, or deliberative one. Aristotle in his Rhetoric (1.3.2.3.) in the following text writes that the 'three genres of speeches of the

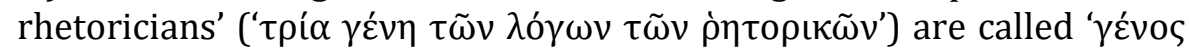

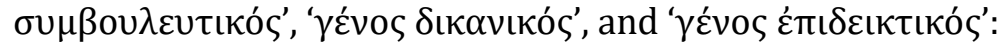

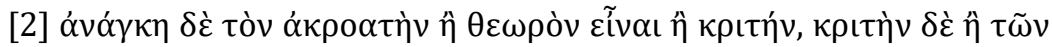

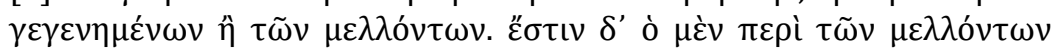

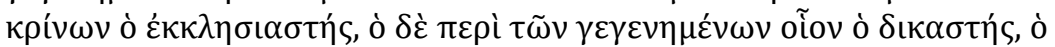

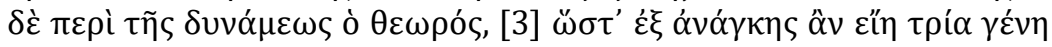

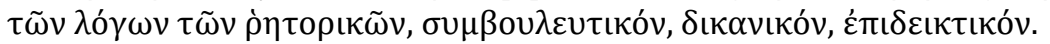
[2] Now the hearer must necessarily be either a mere spectator or a judge, and a judge either of things past or of things to come. For instance, a member of the general assembly is a judge of things to come; 
the dicast, of things past; the mere spectator, of the ability of the speaker. [3] Therefore there are necessarily three kinds of rhetorical speeches, deliberative, forensic, and epideictic.

(Tr. Freese)

Cicero in his Topica (23.91.) and Quintilian in his Institutio Oratoria (3.4.) are the authorities of Roman rhetoric who translated these Greek terms for rhetorical speech into Latin as the 'genus deliberativum', the 'genus iudicale', and the 'genus laudativum'. In the post-classical age, this threefold typology of genres of rhetorical speech continued in the theory of rhetoric. In the digital online project Silva Rhetoricae, Burton distinguishes as 'branches of oratory' ('genera causarum') the 'judicial speech', the 'deliberative speech', and the 'epideictic speech' with reference to classical rhetorical treatises.

Throughout the past, the heritage of the discipline of rhetoric, the canonical three genres of speech (the political speech, the legal speech, and the public speech), was transmitted in the theory of rhetoric and can be even found in the contemporary handbook of rhetoric. The term 'speech genres' is today used even in the tradition of rhetorical studies. Basically, two directions exist for the approach to genres and their tradition in rhetoric. The first is the approach, which considers a continuation of rhetorical genres and their extensions as the aim of the research. An example is Pepe who in Speech Genres in Contemporary Rhetorical Theory discussed the contemporary applicability of the concept of 'speech genres' in the current theory of rhetoric (2013: 519542). The other direction was taken by Tseronis and Forceville (2017) who edited Multimodal Argumentation and Rhetoric in Media Genres, a contemporary study of the rhetorical elements in what they call 'media genres'. Here the concept of the genre is extended as a new framework of rhetorical applications in communication processes beyond orality and the rhetorical elements in it are shown. The terms 'mixed genres' or 'hybrid genres' are often used as a classification for mediated forms of speech, which have both features of orality and direct speech and mediated communication in technical media. An example of a mixed approach is Power, Persuasion and Manipulation in Specialised Genres: Providing Keys to the Rhetoric of Professional Communities, edited by Breeze and published in 2017, a work that employs the term 'specialized genres' in order to describe non-traditional text types as rhetorical genres exceeding the limits of the traditional genres of rhetoric.

\section{Speech and Media Studies: Extensions of the Transmission}

In 1964 MacLuhan in Understanding Media: The Extensions of Man, in the chapter The Spoken Word. Flower of Evil?, stated that new media extend the human senses and nerves to global communication. It is a humanistic approach that aimed at explaining media as means of the 
extension of functions of the human body. In his late work Laws of Media: The New Science, MacLuhan pointed out, with a reference to Shannon and Weavers Mathematical Theory of Communication (1948), how the different media of oral speech and speech communicated operate with the example of the medium radio:

\begin{abstract}
"In oral speech, the information source is the brain, the transmitter is the voice mechanism producing the varying sound pressure (the signal) which is transmitted through the air (the channel). In radio, the channel is simply space (or the aether, if any one still prefers that antiquated and misleading word), and the signal is the electromagnetic wave which is transmitted" (1989: 86).
\end{abstract}

The digitalization process has brought about the transformation of legacy media and new, exclusively digitally encoding media. Genres on the Web. Computational Models and Empirical Studies (2011) contains studies in computational models of genres in the digital area. Mehler, Santini, and Sharoff in Riding the Rough Waves of Genre on the Web described the state of empirical and computational research of what they called 'webgenre', while showing the interdisciplinarity of the concept genre, recent interpretations, and open issues that relate to the modeling of the concept of 'webgenre' in empirical and computational studies (2011: 3-33). Multimedia in the Dictionary of Media and Communications is defined as "multimedia computer system that allows the user to manipulate and use different types of media, such as text, sound, video, graphics, and animation" (2009: 203-204). Products of multimedia applications as contents with units of text (writing), images (still images and moving images), video and audio sequences, graphic elements, and interactive features are good examples for the variety of generic media types of the contemporary media landscape. The concept of 'multimedia' allows us to label the units of products in digital media, whereas multimedia phenomena existed in the time before the computer was used. Within the technical framework of a digital computer network, the concept of multimedia is also applicable for the products or digital contents that combines text, sound, video, graphics, and animation.

\title{
Part II. A model as a contribution to the theory of speech
}

After we have shown several ways how speech can be understood and conceptualized in Part I., we want to look now at a model for the explanation of the speech with a focus on the differences as specific functions of speech. The functions do not exclude each other but 
exist besides each other. Therefore, we chose the conceptual term 'dimensions' in order to describe these functions of speech.

\section{The model of the conceptual dimensions of the functions of speech}

As for the theoretical background of studies of genres of speech, even for the theory of rhetoric, we must take into account more aspects than only the three genres of rhetorical speech, which are the traditional genres in rhetorical theory. We use an approach with multiple dimensions of 'speech'. The dimensions that we introduce here are the following: (1) The dimension of speech refers to any realization of language as linguistic elements. (2) The dimension of spoken speech refers exclusively to the linguistic variety of oral communication. (3) The dimension of the discourse refers to any discourse topic across genres and text types. (4) The dimension of rhetorical speech comprises the doctrine and use of traditional rhetorical genres and rhetorical elements in text types. (5) The dimension of the mediated speech refers to the particular medium employed for the speech.

(1) Speech as a representation of language

(2) Speech as an utterance

(3) Speech as a discourse

(4) Speech as a rhetorical genre

(5) Speech in a mediated realization
Conceptual realization

Unique realization

Topic-determined realization

Rhetorical realization

Realization as mediated

speech

Table 1. The Five Dimensions of Speech

The model of the conceptual dimensions of speech aims at breaking the concept of speech down to the simplest notions that have been formed about it by humans who are able to access it in a reflective and inquiring way of mental cognition. The model aims at explaining the phenomenon of multiple meanings attached to the concept from a functional perspective of its usage. 
1. The Dimension of Speech as Representation

2. The Dimension of Spoken Speech

3. The Dimension of the Discourse

4. The Dimension of Rhetorical Speech

5. The Dimension of the Medium of Speech
Realization of Language

as a Linguistic Representation

Linguistic Variety of Oral

Communication

Discourse Topics and their

Invention across Genres and Text

Types

Traditional Rhetorical Genres and

Rhetorical Elements in Text Types

Technical Realization of Speech in

Media

Table 2. The Five Dimensions of Speech

The most general dimension is the one of speech as the representation of language as the realization (1). This is the overarching function for all other functions, which is based on the idea that an abstract concept like language has an application and realization, namely speech. As a realization of language, speech is the physical phenomenon of an utterance (2) that is realized in any linguistically constructed sequence of human vocal expressions. When speech as such concrete linguistic expressions of language shares a common topic, it can be classified as a discourse (3). The discourse exceeds the linguistic sequence of a single utterance of one speaker. The number of participants and statements made about the topic in a particular discourse can be theoretically unlimited. When particular rhetorical elements for the production of speech are used (for example the 'steps of the production of speech', 'parts of the speech', one of the three 'genres' of deliberative, juridical, or epideictic speech), or stylistic and argumentative principles) a rhetorical speech (4) in accordance with the classical definition of it is produced. The above-mentioned kinds of speeches are described by the default situation of communication by spoken language. De facto, we experience speech today in more than the actual default situation. We can produce and communicate speech in the media. Such mediated speech has increased in the history of human civilization due to the increasing amount of media. Any speech occurs in a specific environment of its mediated realization as a mediated speech (5), for example as a public speech in front of an audience, in a chat with a written conversation of a text messaging service, or in a talk show on TV. 


\section{The Model as Topological Network}

The five dimensions of speech are spaces associated with categories, which can be applied as characteristic categories for the description of any speech. Let us take the example of a contemporary type of speech on the mass media. The live performance of an inauguration speech of a newly elected president of a country as an uttered speech of the person in front of an audience broadcasted on television (speech as utterance) has a clear mediated format of TV broadcasting (speech as mediated realization). It is a representation of the rhetorical speech genre of the 'deliberative speech' (speech as rhetorical genre) and a contribution to the political discourse of the country (besides other discourses) (speech as discourse) as an application of the abstract concept of the language as a concrete speech (representation of language).

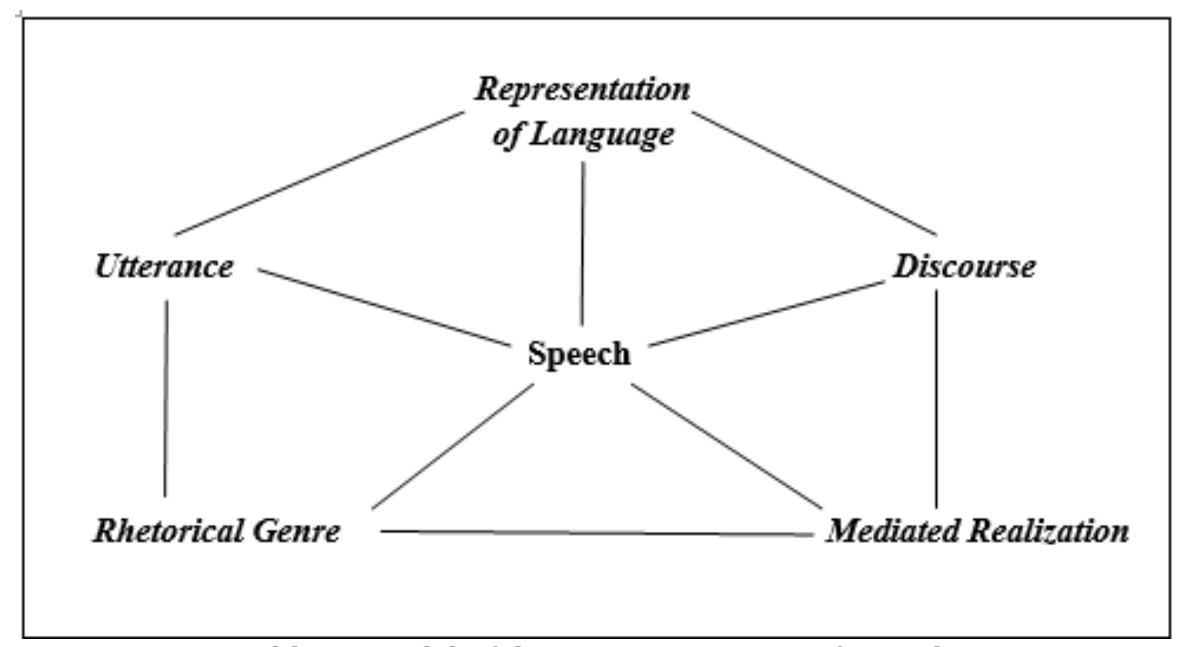

Table 3. Model of the Five Dimensions of Speech:

Categories for the Classification of Speech

The topological characteristics and conditions of oral speech vary and can be classified in three settings of (A) an unmediated environment as an oral 'live' presentation, (B) speech in legacy media, (C) and speech in new media: 


\begin{tabular}{l|l|l|l} 
Who & $\begin{array}{l}\text { Speaker(s) } \\
\text { Audience / } \\
\text { Receiver(s) }\end{array}$ & $\begin{array}{l}\text { Speaker(s) } \\
\text { Audience / } \\
\text { Receiver(s) }\end{array}$ & $\begin{array}{l}\text { Speaker(s) } \\
\text { Audience / } \\
\text { Receiver(s) }\end{array}$ \\
\hline Where & $\begin{array}{l}\text { Speech as an } \\
\text { exchange of human } \\
\text { bodies in a natural } \\
\text { environment }\end{array}$ & $\begin{array}{l}\text { Speech in a } \\
\text { mediated } \\
\text { environment }\end{array}$ & $\begin{array}{l}\text { Speech in a digital } \\
\text { mediated } \\
\text { environment }\end{array}$ \\
\hline Hhen & $\begin{array}{l}\text { In a complete 'time- } \\
\text { space unit' }\end{array}$ & $\begin{array}{l}\text { In a physical } \\
\text { medium in a } \\
\text { complete or } \\
\text { discontinued 'time- } \\
\text { space unit' }\end{array}$ & $\begin{array}{l}\text { In a digitalized } \\
\text { physical medium in } \\
\text { a complete or } \\
\text { discontinued 'time- } \\
\text { space unit' }\end{array}$ \\
\hline \multirow{2}{*}{$\begin{array}{l}\text { Direct Speech } \\
\text { In print or } \\
\text { broadcasting media } \\
\text { communicated } \\
\text { speech }\end{array}$} & $\begin{array}{l}\text { Digitally encoded } \\
\text { speech in an } \\
\text { environment of } \\
\text { digital media }\end{array}$ \\
\hline & $\begin{array}{l}\text { Oral Speech in a } \\
\text { Non-mediated } \\
\text { Environment (A) } \\
\text { Table 4. Topoech in Mecha- } \\
\text { of Oral Speech, Speech in Legacy Media, and Speech in New Media } \\
\text { Legacy Media (B) }\end{array}$ & $\begin{array}{l}\text { Speech in New } \\
\text { Media (C) }\end{array}$ \\
\end{tabular}

In the natural environment with a 'time-space unit' like in the kairos-situation with a speech given by a speaker to an audience in one place and time, the presentation of speech is live and direct. The communication takes directly place between the human entities involved in the performance. On the contrary, in mechanically mediated communication (e.g. handwritten letter) and speech of the legacy media (printed materials, radio, television, and film) the 'time-space unit' for the producer of the speech and the receiver of the speech does not exist any longer. In 'live' communication, for example, the broadcasting of a live event on television, the time unit is stable, while the place is not shared among the sender(s) and the receiving audience(s). Also for the speech of the new media, for example in the case of the streaming of a live event, this effect of the dislocation with a fragmented inconsistency of the place and a shared time exists. 


\section{Part III. The rhetorization of dimensions of speech in the theory of rhetoric}

In this Part III. we will show how the dimensions of the concept of speech, which we introduced in the previous parts, correspond to categories of the theory of rhetoric. The theory of rhetoric is, in its broadest definition, the sum of all knowledge of about rhetoric that is developed by the rhetorica docens and is codified in rhetorical treatises, handbooks, and other scholarly works or artifices reflecting this knowledge about rhetoric. The categories of the system in the theory of rhetoric allow the implementation of the five dimensions of speech we introduced above into the theory of rhetoric.

\section{The Rhetorization of Dimensions of Speech}

The previously in Part II. introduced dimensions of speech that can be traced back to the system of the discipline rhetoric.

(1) Speech as a representation of language concerns the conceptual realization of an abstract concept. This area is in the theory of rhetoric known as the 'res'-'verba' relation. In his Institutio Oratoria (1.5.2.), the teacher of rhetoric of the late Roman Empire - Quintilian, quotes Horace's sentence 'Verbaque provisam rem non invita sequentur' to refer to the practice of keeping things in mind in order to succeed with the words of one's speech:

[2] verba nunc generaliter accipi volo, nam duplex eorum intellectus est; alter, qui omnia per quae sermo nectitur significat, ut apud Horatium: "verbaque provisam rem non invita sequentur".

[2] I must now be understood to use verbum in its most general sense. It has of course two meanings; the one covers all the parts of which language is composed, as in the line of Horace: Once supply the thought, And words will follow swift as soon as sought;

(Tr. Edgeworth Butler)

This relation of 'things' and 'words' was in the modern theory of rhetoric revived by Austin in his book How To Do Things With Words (1962) and recently discussed from various perspectives in a collection of articles with the title Das Verhältnis von res und verba: $\mathrm{Zu}$ den Narrativen der Dinge, edited by Wernli and Kling (2018). The systematic area of rhetoric for this dimension of speech is the 'invention'.

(2) Speech as an utterance refers to the unique realization of speech, an area, which is as speech production traditionally described in the treatises of the 'rhetorica utens'. The 'parts of the rhetorical speech' ('partes orationis') are the structural units of rhetorical speech production. In his discourse about elocution (Institutio Oratoria (8. Pr. 78)), Quintilian mentions the three functions of speech in rhetoric: The 
'teaching' ('docere'), the 'delighting' ('delectare'), and the 'moving' ('movere') of the speech. This distinction was used by Wagner in Rhetorica Docens et Utens, Eloquentiae Candidatum Non minus Imbuens Praeceptis, Quam Exemplis Dirigens, a manuscript produced at the monastery of the Tegernsee in 1734. In Tra 'Rhetorica Utens' $e$ 'Rhetorica Docens'. Domande e Offerte in Alcuni Settori del Variegato Panorama Attuale, Garavelli (2004: 5-18) applied the distinction to a postmodern environment. The systematic area of rhetoric for this dimension of speech is the 'disposition'.

(3) Speech as a discourse and as a topic-related realization of speech can be traced to the areas of argumentation and topology and the invention of speech. In his Topica, Aristotle treated this part of rhetorical theory showing how the 'places' ('topoi') can be used as the seats for the arguments. Cicero in his De Inventione (1.2.) uses the concept of the place ('locus') when he describes the process of civilisation as the gathering of previously dispersed humans 'with a certain method' ('ratione quadam') 'in one place' ('unum in locum') and the beginning of a communicative situation with a 'rhetorical speech' ('oratio'): ("Qui dispersos homines in agros et in tectis silvestribus abditos ratione quadam conpulit unum in locum et congregavit et eos in unam quamque rem inducens utilem atque honestam primo propter insolentiam reclamantes, deinde propter rationem atque orationem studiosius audientes ex feris et inmanibus mites reddidit et mansuetos"). In this passage, Cicero describes how the humans have to adapt to the novelty with complaints ("propter insolentiam reclamantes") in this process of being introduced to a 'useful and honorable thing' ('res utilis atque honesta') ("et eos in unam quamque rem inducens utilem atque honestam"). We can interpret this process as the emergence of a discourse that is established by the powerful individual orator who speaks to the group of people. The form is an aspect of rhetorical production. Recently, Kirkbride (2013) edited a set of articles with the title Geometries of Rhetoric, concerning the relationship of geometric and literary figures in human cognition, figures as instruments of inquiry, and the environment of various historical and contemporary artifices. The systematic area of rhetoric for this dimension of speech as topic-related discourse is the 'memory'.

(4) Speech as a rhetorical genre for the realization of rhetoric refers to the area of 'elocutio' and style. Since the antique theory of rhetoric recorded principles of rhetoric, 'elocution' ('elocutio') is a production step of speech after the 'invention' and 'disposition' followed by the 'memory' and 'delivery'. So, in his Institutio Oratoria (3.3.), Quintilian mentions as the steps for the production of a speech 'invention' ('inventio'), 'disposition' ('dispositio'), 'elocution' ('elocutio'), 
'memory' ('memoria'), and 'pronunciation' or 'delivery' ('pronuntiatio' and 'actio'):

[3] omnis autem orandi ratio, ut plurimi maximique auctores tradiderunt, quinque partibus constat, inventione, dispositione, elocutione, memoria, pronuntiatione sive actione, utroque enim modo dicitur.

[3] The art of oratory, as taught by most authorities, and those the best, consists of five parts: invention, arrangement, expression, memory, and delivery or action (the two latter terms being used synonymously).

(Tr. Edgeworth Butler)

In contemporary rhetorical handbooks and contributions for the research of the theory of rhetoric, the traditional terms of the organization of the steps of the speech production are still employed. So, for example, in Digital Rhetoric, Eyman activated the canons of speech for a digital environment as 'invention', 'arrangement', 'style', 'delivery', and 'memory'. The systematic area of rhetoric for this dimension of speech is the 'style' (2015: 65).

(5) Speech as a mediated realization of speech with a reference to the traditional area of rhetoric is in the classical theory of rhetoric described as the 'kairos'-situation. The presentation of speech in the media in the theory of rhetoric was first described in oral speech but is not limited to this mediating scenario. In his Institutio Oratoria (2.20.1.), Quintilian discusses the place of rhetoric 'among the contemporary middle arts' ('ex mediis artibus'), which cannot be praised or scolded since they are purely 'useful' ('utiles'):

illa quaestio est maior, ex mediis artibus, quae neque laudari per se nec vituperari possunt, sed utiles aut secus secundum mores utentium fiunt, habenda sit rhetorice, an sit, ut compluribus etiam philosophorum placet, virtus.

More important is the question whether rhetoric is to be regarded as one of the indifferent arts, which in themselves deserve neither praise nor blame, but are useful or the reverse according to the character of the artist; or whether it should, as not a few even among philosophers hold, be considered as a virtue.

(Tr. Edgeworth Butler)

Quintilian here set the framework of rhetoric not only as a genuine art that produces artifices but also as a technical skill that has the function of a medium. In Multimodal Argumentation and Rhetoric in Media Genres (2017), edited by Tseronis and Forceville, the rhetoric of empirical multimodal 'media genres' was inquired for legacy media and 
new media. The systematic area of rhetoric for this dimension of speech is the 'delivery'.

The dimensions of speech and their actualization in the system of the discipline rhetoric are described here:

\begin{tabular}{|c|c|c|c|c|}
\hline 1. & $\begin{array}{l}\text { Speech as the } \\
\text { representation } \\
\text { of language }\end{array}$ & $\begin{array}{l}\text { Conceptual } \\
\text { realization }\end{array}$ & Res-Verba relation & 'Invention' \\
\hline 2. & $\begin{array}{l}\text { Speech as an } \\
\text { utterance }\end{array}$ & $\begin{array}{l}\text { Unique } \\
\text { realization }\end{array}$ & $\begin{array}{l}\text { Speech Production } \\
\text { Rhetorica Utens }\end{array}$ & 'Disposition' \\
\hline 3. & $\begin{array}{l}\text { Speech as a } \\
\text { discourse }\end{array}$ & $\begin{array}{l}\text { Topic- } \\
\text { determined } \\
\text { realization }\end{array}$ & $\begin{array}{l}\text { Argumentation } \\
\text { and Topology }\end{array}$ & 'Memoria' \\
\hline 4. & $\begin{array}{l}\text { Speech as a } \\
\text { rhetorical } \\
\text { genre }\end{array}$ & $\begin{array}{l}\text { Rhetorical } \\
\text { realization }\end{array}$ & Style & 'Elocution' \\
\hline 5. & $\begin{array}{l}\text { Speech in a } \\
\text { mediated } \\
\text { realization }\end{array}$ & $\begin{array}{l}\text { Realization as } \\
\text { mediated speech }\end{array}$ & Kairos-situation & 'Delivery' \\
\hline
\end{tabular}

Table 5. Dimensions of Speech in the System of the Discipline Rhetoric

The production stages of the speech can be associated with the conceptual areas of speech. (1) Speech as a representation of language can be structurally associated with the first production step of a speech, the 'invention'. (2) Speech as an utterance is the actual arrangement of the material of this invented materialization of language in speech as 'disposition', which is in the second step in the production process of rhetorical speech. (3) Speech as a discourse is a form of speech for information exchange, which refers to the fourth step in the production process of rhetorical speech, the 'memoria'. (4) Speech as a rhetorical genre is characterized by the stylistic form chosen, which is in the production steps of rhetorical speech the third step, the 'elocution'. (5) Speech in a mediated realization refers to the fifth step of the production of rhetorical speech, the 'delivery'.

\section{Extensions of the theory of rhetoric to contemporary media}

Speech in mediated environments can be distinguished into oral speech in a non-mediated environment (A), speech in legacy media (B), and speech in new media (C). In this section we look at these extensions of the previously described categories of the theory of rhetoric for the dimensions of speech to contemporary media, which fall into the categories A, B, or C. The five canons of rhetoric as the normative 
production stages of rhetoric and their general functions can be used for the classification of contemporary speech:

(1) The production stage 'invention' of the speech

(2) The production stage 'disposition' of the speech

(3) The production stage 'elocution' of the speech

(4) The production stage 'memory' of the speech

(5) The production stage 'delivery' of the speech
Function: Finding

Function: Ordering

Function: Forming

Function: Recording

Function: Presentation

Table 6. The Five Canons of Rhetoric:

Production Stages and their Function

\section{(1) Media, 'Invention' and Speech as a Representation of Language}

We mentioned that speech as a representation of language concerns the conceptual realization of speech in a real environment. In the theory of rhetoric the 'res'-'verba' relation establishes the relation between the things and the words and the systematic area of the 'invention'. Any systematic means of symbolic communication, for example, speech and writing, but also other carriers of mediated elements of symbolic communication, can establish a relation between the 'things' of reality and 'words'. 'Things' and 'words' are in rhetorical theory considered to be the relation for persuasion. 'Words' are in the default 'kairos'-situation delivered to an audience in order to change 'things'. Media are a bridge crossing physical and temporal distances that did not exist in the unit of the 'kairos'-situation. Legacy media (print products, radio, TV, film) can entail speech with such a persuasive structure, but the unit of time and place does not exist any longer. A direct interaction does not take place any longer between the participating speakers. Mediated communication replaces direct interpersonal communication.

Contemporary media with digital encoding processes of information allow interaction between the communicators who operate in a framework of various degrees of the separation of time and location. In a computer, the technical elements, which refers to the area of the 'invention', are the components that allow the finding of information like the software of the operating system and the hardware components chassis, central processing unit (CPU, motherboard, monitor, keyboard, computer data storage/memory, graphics card, sound card, and speakers. Among the media of the contemporary media landscape, which support the 'invention', are media that particularly enable their users to access data and information. Examples for contemporary media, which cover the area the systematic area of the 'invention' are data storage-accessing means like protocols, search engines, and databases. These media are providers of the inventory of contents. 


\section{(2) Media, 'Disposition' and Speech as an Utterance}

We associated speech as an utterance with the unique realization of speech as speech production, which in the theory of rhetoric is traditionally described as 'rhetorica utens', the application of rhetorical theory in contrast to 'rhetorica docens'. The 'parts of the rhetorical speech' ('partes orationis') are the structural units of a rhetorical speech. The 'disposition' is the step of the arrangement of the rhetorical speech. Normative rhetorical speech consists of structural units. Speech here is the medium. As contents in other media or as speech implemented into other media speech can be communicated. Legacy media allow the recording and transmission of speech as uttered symbolic communication as well as traditional rhetorical speeches.

Contemporary media with digital encoding can be the mediating means for the production, recording, and transmission of speech as an utterance and rhetorical speech. The 'disposition' refers as a structural category to contemporary media like emailing-systems, short-message systems, websites as contents-carriers, or any media that are able to represent speech as an utterance in the digitalized environment of contemporary computers. Technically, in a computer the arrangement of information, the software has the function to arrange the information ranging from software of operating system of the computer, to particular software types for the library, the data (e.g. the protocol), the interface of the computer and its particular applications for the users, which commonly fall in the areas of text production software ('office software'), software for graphic design, software for audio production, and software for video production, which allow the creation of multimedia products, but can be customized for the individual needs of the user. Among the media of the contemporary media landscape, which support the 'disposition', are the media that enable the action of the communicative exchange of data and information.

\section{(3) Media, 'Memory' and Speech as a Discourse}

The conceptualization of speech as a discourse and as the topicdetermined realization of speech is in the theory of rhetoric associated with the areas of argumentation and topology and the systematic area of the 'memory'. As for symbolic communication systems like oral or written speech, they can be meditated in other media, while contributing to the same topic. The mediated speeches form the set of discourse units, each of them with a particular argumentative position, which contributes to the discourse. All contributions to the discourse can be understood as the topological structure of the particular discourse. Legacy media can contribute to the discourse about a particular topic. The sum of the contributions about a particular topic in legacy media, for 
example, radio features, news reports, or newspaper articles and books, is the discourse about the topic. Its topological structure is expanded over several types of media.

In a computer, the storage devices are the processing elements like the central processing unit (CPU), the sound card, the CD-Rom drive, and the plug for the USB-flash that technically support the 'delivery'. In the contemporary media landscape, the media with the function of recording information like content systems refer to the function 'delivery'. Contemporary media with digital encoding allow an extension of a particular discourse in the area of digital media. The systematic area of the 'memory' as a category for speech is related to the contemporary medium of the internet and any device with the function to present speech in any formation that can contribute to a discourse. The network and hardware/software of a device enable this function.

\section{(4) Media, 'Elocution' and Speech as a Rhetorical Genre}

We mentioned that speech as a rhetorical genre for the realization of rhetoric refers to the area of 'elocution' and style in the theory of rhetoric. The style of the chosen wording of a speech can be presented in any mediated form. Legacy media can produce, record, and transmit speech as mediated contents with stylistic features. Contemporary media with digital encoding allow an extension of the production, recording, and transmission of speech in digitalized formats.

The 'elocution' is structurally present in the contemporary media, which are able to represent rhetorical speech or its features. Among them are any devices or programs for the recording of sound or writing. In a computer, the technical elements, which allow the production for contents as the application of the 'elocution', the input devices like the keyboard, mouse, and the interface displayed on the screen are associated with this function. As for the media in the contemporary landscape that support the 'elocution', they must have the feature of creating and designing text of writing or oral speech other any other carrying medium for the formation of text like text and graphic design programs, communication systems of emailing providers, providers of short message services, and social media. Any website has the potential to implement text as a formative element.

\section{(5) Media, 'Delivery' and Speech as a Rhetorical Genre}

Speech in a mediated realization of speech refers to the area of the theory of rhetoric describing the 'kairos'-situation. In media, which are not embedded into the default 'kairos'-situation with a unit of the time and place, the 'kairos'-situation does not exist. This situation is associated with the step of 'delivery' in the production process of a 
rhetorical speech. Legacy media do not have the unit of time and location when communication via speech takes place.

Contemporary media with digital encoding also convey speech no longer in a unit like in the 'kairos'-situation, but allow an instant and timely exchange. Contemporary media associated with the step of 'delivery' are any media, which allow the speech to be displayed. Output devices like graphic and speaker units and the screen with the interface technically support the 'delivery'. Media that present complete media products for the consumption of the audience can be classified as media with the classical function of 'delivery'. Structurally, the interface of a device enables the use of this function.

\section{Conclusion}

The theory of rhetoric is not limited to a description of the function of speech in the particular 'rhetorical situation' of the system of rhetoric. Based on the traditional theory of rhetoric, we can describe the current contemporary states of speech in mediated environments that employ media. Direct communication exceeds the 'rhetorical situation' in these mediated environments. The current use of speech in media reflects the various aspects of the concept of speech that we described in the first part of the article as the five dimensions of speech. Nevertheless, the rhetorical quality of speech is a genuine feature of speech in any format of the representation of speech. New inventions and media that change the presentation of speech are an ongoing phenomenon. The future of new media is a coming challenge for the theory of rhetoric.

\section{References}

Aristotle. Ars Rhetorica. Ed. W. D. Ross. Oxford: Clarendon Press, 1959. Perseus Project of Tufts University. Web. 23 March 2019. <http://www.perseus.tufts.edu/hopper/text?doc=Perseus:text:1999. $01.0059>$.

---. $\quad$ Rhetoric. Aristotle in 23 Volumes, Vol. 22. Tr. J. H. Freese. Cambridge: Harvard University Press; London: Heinemann, 1926. Perseus Project of Tufts University. Web. 23 March 2019.

<http://www.perseus.tufts.edu/hopper/text?doc=Perseus\%3Atext\% 3A1999.01.0060>.

Association Assyrophile de France. Akkadian Dictionary. Website Association Assyrophile de France. Web. 23 March 2019. <http://www.assyrianlanguages.org/akkadian/dosearch.php>.

Bakhtin, Michail M. Speech Genres and Other Late Essays. Estetika Slovesnogo Tvorchestva. Ed. Caryl Emerson. Austin, TX: U of Texas P; 2007.

---. $\quad$ Speech Genres and Other Late Essays. Tr. Vern W. McGee. Ed. Caryl Emerson and Michael Holquist. Austin, TX: U of Texas P, 1986. 
Berwick, Robert C., Johan J. Bolhuis, Noam Chomsky, and Ian Tattersall. "How Could Language Have Evolved?” PLoS Biology 12.8 (2014): 1-6. Web. 23 March 2019. $<$ https://doi.org/10.1371/journal.pbio.1001934 >.

Breeze, Ruth, ed. Power, Persuasion and Manipulation in Specialised Genres: Providing Keys to the Rhetoric of Professional Communities. Bern: Peter Lang, 2017.

Bruce, Ian. "Evolving Genres in Online Domains: The Hybrid Genre of the Participatory News Article." In: Genres on the Web. Computational Models and Empirical Studies. Ed. Alexander Mehler; Marina Santini; Serge Sharoff. Dordrecht: Springer Science + Business Media B.V., 2011: 323-348.

Burton, Gideon O., ed. "Branches of Oratory.” Silva Rhetoricae. Brigham Young University. Web. 23 March 2019.

$<$ http://rhetoric.byu.edu>.

Cicero, Marcus Tullius. Rhetorici Libri Duo qui Vocantur de Inventione. Ed. Eduard Stroebel. Leipzig: Teubner, 1915. Perseus Project of Tufts University. Web. 23 March 2019. <http://www.perseus.tufts.edu/hopper/ >.

Danesi, Marcel, ed. Dictionary of Media and Communications. Armonk, NY and London: Sharpe, 2009.

Dictionary Entry Lookup Tool. Perseus Project of Tufts University. Web. 23 March 2019.

<http://www.perseus.tufts.edu/hopper/search>.

Erman, Adolf and Hermann Grapow, eds. Wörterbuch der Ägyptischen Sprache. Vol. I-V. Unchanged Reprint. Berlin: Akademie-Verlag, 1971.

Erman, Adolf and Hermann Grapow, eds. Wörterbuch der Ägyptischen Sprache. Vol. VI. Deutsch-Ägyptisches Wörterverzeichnis. Berlin: AkademieVerlag and Leipzig: Hinrichs, 1950.

Eyman, Douglas. Digital Rhetoric. Theory, Method, Practice. Ann Arbor: U of Michigan P, 2015.

Forceville, Charles and Assimakis Tseronis, eds. Multimodal Argumentation and Rhetoric in Media Genres. Amsterdam: John Benjamins, 2017.

Garavelli, B.M. “Tra 'Rhetorica Utens' e 'Rhetorica Docens': Domande e Offerte in Alcuni Settori del Variegato Panorama Attuale." Intersezioni 24.1 (2004): 5-18.

Gash, Hugh, José Luis Usó-Doménech, and Josué Antonio Nescolarde-Selva. "Universe of Discourse and Existence". Mathematics 272.6 (11) (2018): 1-19. <https://doi.org/10.3390/math6110272>.

Holden, Constance. "The Origin of Speech". Science 303.5662 (2004): 13161319. Web. 23 March 2019.

DOI: $10.1126 /$ science.303.5662.1316

Kirkbride, Robert, ed. Geometries of Rhetoric. Berlin: Springer, 2013.

Kling, Alexander and Martina Wernli, eds. Das Verhältnis von res und verba: $Z u$ den Narrativen der Dinge. Freiburg i.Br.; Berlin; Wien: Rombach, 2018.

Marcuse, Herbert. One-Dimensional Man: Studies in the Ideology of Advanced Industrial Society. Boston: Beacon, 1964. 
McLuhan, Eric, and Marshall McLuhan. Laws of Media: The New Science. Toronto, Buffalo, London: U of Toronto P, 1989.

McLuhan, Marshall. Understanding Media: The Extensions of Man. New York: McGraw Hill, 1964.

Mehler, Alexander, Marina Santini, and Serge Sharoff. "Riding the Rough Waves of Genre on the Web". In: Genres on the Web. Computational Models and Empirical Studies. Ed. Alexander Mehler, Marina Santini, Serge Sharoff. Dordrecht: Springer Science + Business Media B.V., 2011: 3-33.

Pepe, Cristina. "Appendix: Speech Genres in Contemporary Rhetorical Theory." In: The Genres of Rhetorical Speeches in Greek and Roman Antiquity. Ed. Cristina Pepe. Leiden; Boston: Brill, 2013: 519-542. Web. 23 March 2019. DOI: https://doi.org/10.1163/9789004258846_025

<https://brill.com/view/book/9789004258846/B9789004258846_0 25.xml>.

Quintilian, Marcus Fabius. Institutio Oratoria. Tr. Harold Edgeworth Butler. Cambridge, Mass.: Harvard University Press; London: Heinemann, 1920. Perseus Project of Tufts University. Web. 23 March 2019.

<http://www.perseus.tufts.edu/hopper/text?doc=Perseus\%3atext\%3a2007.0 $1.0060 \% 3 a$ book $\% 3 \mathrm{~d} 1>$.

Saussure, Ferdinand de. Cours de Linguistique Générale, Ed. Charles Bally and Albert Sechehaye. Paris: Payot, 1971.

Starostin, Sergey, ed. Tower of Babel Project. An Etymological Database Project. Web. 23 March 2019. $<$ http://starling.rinet.ru>.

Tannen, Deborah. "Discourse Analysis: What Speakers Do in Conversation." Discourse Analysis. Linguistic Society of America. Web. 23 March 2019. $<$ https://www.linguisticsociety.org/resource/discourse-analysiswhat-speakers-do-conversation>.

Wagner, Gotthard. Rhetorica Docens et Utens, Eloquentiae Candidatum Non Minus Imbuens Praeceptis, Quam Exemplis Dirigens. Tegernsee: Monasterium Tegernseensis, 1734. Unpublished Manuscript. Bayerische Staatsbibliothek München. Signature L.eleg.g. 434. Bayerische Staatsbibliothek München. Web. 23 March 2019. $<$ https://reader.digitalesammlungen.de/de/fs1/object/display/bsb11081446_00005.html> 